\title{
Seasonal Quality Responses of Perennial Ryegrass as Influenced by Fungicides
}

\section{P.H. Dernoeden and M.S. McIntosh \\ Department of Agronomy, University of Maryland, College Park, MD 20742}

\begin{abstract}
Additional index words. Lolium perenne, red thread, Laetisaria fuciformis, benomyl, chlorothalonil, iprodione, thiram, triadimefon
\end{abstract}

\begin{abstract}
Little is known about deleterious or beneficial nontarget effects of fungicides applied to turfgrasses. Five fungicides from several chemical classes were applied six times annually over 5 years to field plots of either 'Regal' or 'Fiesta' perennial ryegrass (Lolium perenne L.). All fungicides improved turfgrass quality during Spring 1984, Summer 1984 and 1985, Fall 1984, and Winter (except benomyl and chlorothalonil) 1985. Improved quality in Spring 1984 was attributed to red thread [Laetisaria fuciformis (McAlp.) Burds.] control; whereas, improved quality in Summer 1985 was due to brown patch (Rhizoctonia solani Kuhn.) control. For other years and seasons, the mechanism of improved quality provided by the fungicides was not determined. Other than red thread and brown patch control, few nontarget benefits and no nontarget detriments were observed visually with multiple applications of the fungicides evaluated. Chemical names used: methyl[1-butylamino carbonyl]-1H-benzimidazol-2yl]carbamate(benomyl); tetrachloroisophthalonitrile (chlorothalonil); 1-isopropyl-carbamoyl-3-(3,5-dichlorophenyl) hydantoin (iprodione); bis(dimethyl-thio-carbamoyl) disulfide (thiram); and 1-(4-chlorophenoxy)-3,3-dimethyl-1-(1H-1,2,4-triazol-1-y1)-2butanone (triadimefon).
\end{abstract}

Among the deleterious effects occasionally associated with frequent use of selected fungicides is the enhancement of nontarget diseases. For example, red thread was significantly more severe in spring in perennial ryegrass turf treated the previous summer with multiple applications of benomyl (Dernoeden et al., 1985). Conversely, there are nontarget benefits associated with fungicide use. In the absence of visual disease damage, fungicide use was reported to improve quality of perennial ryegrass (Dernoeden et al., 1985) and color of Kentucky bluegrass (Poa pratensis L.) (Kane and Smiley, 1983). Further, fungicides used to control stripe smut [Ustilago striiformis (West.) Niessl.] and red thread diseases were shown to indirectly reduce smooth crabgrass [Digitaria ischaemum (Schreb.) Muhl.] encroachment in turf (Dernoeden, 1989; Demoeden and Krouse, 1990).

Fungicides are used frequently on golf course turf in the United States. There is also a growing interest in commercial lawn care to manage diseases with fungicides while exploiting beneficial nontarget effects, such as improving aesthetic quality and reducing weeds. Little is known, however, about nontarget effects of fungicides applied to turfgrasses (Smiley, 1981). Therefore, the

Received for publication 10 Dec. 1990. Scientific Article no. A6119 and Contribution no. 8284 of the Maryland Agr. Expt. Sta., Dept. of Agronomy, Univ. of Maryland, College Park, MD 20742. The cost of publishing this paper was defrayed in part by the payment of page charges. Under postal regulations, this paper therefore must be hereby marked advertisement solely to indicate this fact. primary objectives of this study were to assess the influence of five fungicides from various chemical classes on the quality of two perennial ryegrass cultivars and to document possible nontarget disease enhancement effects of these fungicides. Because it was the purpose of this investigation to isolate quality responses and nontarget effects of individual fungicides applied to different cultivars, the cultivars were not blended and fungicide treatments were not tank-mixed or rotated.

The study area was established at the Univ. of Maryland Turfgrass Research and Education Facility in Sept. 1981. Soil was a Chillum silt loam (fine silty, mixed mesic Typic Hapludult) with a $\mathrm{pH}$ of 6.8 and 19 mg organic matter/g of soil.

'Fiesta' and 'Regal' perennial ryegrass (PRG) were seeded at $293 \mathrm{~kg}$ seed/ha. Be-

Table 1. ANOVA for quality ratings of two perennial ryegrass cultivars treated with fungicides from 1984-86.

\begin{tabular}{lrcllc}
\hline \hline \multirow{2}{*}{$\begin{array}{l}\text { Sources of } \\
\text { variation }\end{array}$} & & \multicolumn{4}{c}{ Mean squares } \\
\cline { 2 - 6 } & df & Fall & Winter & Spring & Summer \\
\hline Rep & 3 & 1.19 & 0.21 & 1.03 & 0.46 \\
Cultivar (C) & 1 & 0.86 & 1.99 & 1.18 & 0.64 \\
Error a & 3 & 0.47 & 1.31 & 0.58 & 1.58 \\
Fungicide (F) & 5 & $0.85^{* *}$ & $0.54^{* *}$ & $0.44^{*}$ & $1.96^{* *}$ \\
F × C & 5 & 0.08 & 0.16 & 0.09 & 0.18 \\
Error b & 30 & 0.08 & 0.09 & 0.13 & 0.18 \\
Year (Y) & 2 & $20.86^{* *}$ & $49.18^{* *}$ & $1.36^{* *}$ & $27.4^{*}$ \\
Error c & 6 & 0.41 & 0.07 & 0.29 & 0.12 \\
Y $\times$ C & 2 & 0.41 & 0.54 & 0.06 & 0.21 \\
Error d & 6 & 0.19 & 0.27 & 0.26 & 0.23 \\
Y $\times$ F & 10 & $0.54^{* *}$ & $0.72^{* *}$ & $0.28^{* *}$ & $0.34^{* *}$ \\
Y $\times$ C $\times$ F & 10 & $0.07^{*}$ & 0.03 & 0.08 & 0.05 \\
Error e & 60 & 0.03 & 0.06 & 0.08 & 0.07 \\
\hline \hline
\end{tabular}

$* * *$ Significant at $P=0.05$ and 0.01 , respectively. fore seeding, the seedbed was rototilled to a depth of $20 \mathrm{~cm}$, cultipacked, dragged with a steel mat, and graded by hand-raking. A 10N3P-3K fertilizer was applied to supply $75 \mathrm{~kg}$ $\mathrm{N} / \mathrm{ha}$. Individual plots were hand-seeded and raked, and the seedbed was firmed with a roller. The study area turf was mown at 6- to $\mathrm{S}-\mathrm{cm}$ height and was irrigated as required to prevent drought dormancy. The turf was fertilized annually in fall with 100 to $150 \mathrm{~kg} \mathrm{~N} /$ ha from either urea or the $10 \mathrm{~N}-3 \mathrm{P}-3 \mathrm{~K}$ fertilizer. The site was treated each year in fall with a mix of 2,4-D [2,4-dichlorophenoxy acetic acid] + MCPP [2-(methyl-4-chlorophenoxy) propionic acid] + dicamba [3,6-dichloro-oanisic acid] to control broadleaf weeds. In Apr. 1986 and 1987, oxadiazon (3-[2,4-dichloro-5(1-methylethoxy)phenyl]-5-(1,1dimethylethyl)1,3,4-oxadiazol-2-(3H)one) was applied and immediately watered-in for preemergence control of annual grass weeds.

Each fungicide was applied to the same plot midmonth \pm 2 days from Apr. to Sept. 1983 through 1987 for a total of six applications per year per plot for 5 years. The fungicides and rates evaluated were as follows: benomyl, 50WP $3.1 \mathrm{~kg}$ a.i./ha; chlorothalonil 4F, $9.2 \mathrm{~kg}$ a.i./ha; iprodione 50WP, $3.1 \mathrm{~kg}$ a.i./ha; thiram 75WP, 13.8 $\mathrm{kg}$ a.i./ha; and triadimefon $25 \mathrm{WP}, 1.5 \mathrm{~kg}$ a.i./ha. Fungicides were applied in 1020 liters water/ha at $260 \mathrm{kPa}$, and no rain or irrigation followed treatment within $24 \mathrm{~h}$ of application.

The experiment was conducted as a split plot in a randomized complete-block design with four replications. The cultivar main plots were $3 \times 6 \mathrm{~m}$ and the fungicide subplots were $1 \times 3 \mathrm{~m}$. Overall quality and disease injury were determined midmonth \pm 2 days from Apr. 1984 through Mar. 1987. Overall quality was assessed visually on a 0 to 10 scale where $0=$ brown or dead turf and $10=$ optimum density and greenness. Red thread and brown patch injury were rated visually on a $0 \%$ to $100 \%$ scale where $0 \%$ $=$ entire plot area green and healthy and $100 \%=$ entire plot area blighted.

Ratings for red thread and brown patch were subjected to arcsin transformation for analysis of variance (ANOVA) and mean separation; however, only the actual per- 
Table 2. Turfgrass quality ratings pooled from two perennial ryegrass cultivars treated with fungicides from 1984-86.

\begin{tabular}{|c|c|c|c|c|c|c|c|c|c|c|c|c|}
\hline \multirow[b]{3}{*}{ Fungicide } & \multicolumn{12}{|c|}{ Turfgrass quality ${ }^{2}$ (rating) } \\
\hline & \multicolumn{3}{|c|}{ Spring } & \multicolumn{3}{|c|}{ Summer } & \multicolumn{3}{|c|}{ Fall } & \multicolumn{3}{|c|}{ Winter } \\
\hline & 1984 & 1985 & 1986 & 1984 & 1985 & 1986 & 1984 & 1985 & 1986 & 1985 & 1986 & 1987 \\
\hline Benomyl & $8.4^{*}$ & 8.8 & 8.4 & $6.4^{*}$ & $7.0^{*}$ & 8.0 & $7.9^{*}$ & 9.0 & 7.8 & 6.6 & 5.2 & 7.2 \\
\hline Triadimefon & $8.6^{*}$ & 8.7 & 8.7 & $6.9^{*}$ & $7.3^{*}$ & 8.0 & $8.4^{*}$ & 9.0 & 8.1 & $6.7^{*}$ & $5.6^{*}$ & 7.3 \\
\hline Iprodione & $8.7^{*}$ & 9.0 & 8.7 & $6.6^{*}$ & $7.1^{*}$ & 7.9 & $8.3^{*}$ & 9.3 & 8.0 & $7.2^{*}$ & 5.5 & 7.4 \\
\hline Chlorothalonil & $8.4^{*}$ & 8.7 & 8.5 & $6.2^{*}$ & $6.9^{*}$ & 7.7 & $7.6^{*}$ & 9.1 & 8.0 & 6.3 & 5.4 & 7.3 \\
\hline Thiram & $8.6^{*}$ & 8.7 & 8.3 & $6.5^{*}$ & $6.9^{*}$ & 7.7 & $7.8^{*}$ & 8.9 & 7.9 & $6.8^{*}$ & 5.3 & 7.4 \\
\hline None (control) & 7.9 & 8.8 & 8.6 & 5.4 & 6.5 & 7.8 & 7.1 & 9.1 & 7.9 & 6.4 & 5.3 & 7.3 \\
\hline $\mathrm{LSD}, P=0.05^{y}$ & & 0.3 & & & 0.3 & & & 0.2 & & & 0.2 & \\
\hline
\end{tabular}

Turfgrass quality was assessed visually on a 0 to 10 scale where $0=$ brown or dead turf and $10=$ optimum density and greenness.

'LSD values can be used to compare fungicide-year means within a season.

*Treatment is significantly different from the untreated control at $P=0.05$.

Table 3. Red thread and brown patch blighting of perennial ryegrass as affected by fungicides.

\begin{tabular}{lccccc}
\hline \hline & \multicolumn{4}{c}{ Plot area blighted (\%) } \\
\cline { 2 - 5 } & \multicolumn{4}{c}{ Red thread } & Brown patch \\
\cline { 2 - 5 } Fungicide & 1984 & 1987 & July 1984 & Dec. 1986 & July 1985 \\
\cline { 2 - 5 } & $1 \mathrm{a}^{\mathrm{y}}$ & $6 \mathrm{~b}$ & $2 \mathrm{a}$ & $4 \mathrm{~b}$ & $0 \mathrm{a}$ \\
Benomyl & $0 \mathrm{a}$ & $<1 \mathrm{a}$ & $0 \mathrm{a}$ & $0 \mathrm{a}$ & $0 \mathrm{a}$ \\
Triadimefon & $1 \mathrm{a}$ & $1 \mathrm{a}$ & $<1 \mathrm{a}$ & $1 \mathrm{a}$ & $0 \mathrm{a}$ \\
Iprodione & $2 \mathrm{a}$ & $5 \mathrm{~b}$ & $1 \mathrm{a}$ & $1 \mathrm{a}$ & $2 \mathrm{a}$ \\
Chlorothalonil & $1 \mathrm{a}$ & $1 \mathrm{a}$ & $1 \mathrm{a}$ & $1 \mathrm{a}$ & $2 \mathrm{a}$ \\
Thiram & $20 \mathrm{~b}$ & $12 \mathrm{c}$ & $14 \mathrm{~b}$ & $4 \mathrm{~b}$ & $9 \mathrm{~b}$ \\
None (control) & & &
\end{tabular}

${ }^{2}$ Estimates of percent of plot area blighted by red thread or brown patch were visually assessed on a $0 \%$ to $100 \%$ scale where $0 \%=$ no injury and $100 \%=$ entire plot area blighted.

'Mean separation in columns by LSD at $P=0.05$; LSD calculated on arcsin-transformed data.

centages are shown. For overall quality, only data collected from Apr. 1984 through Mar. 1987 were analyzed. All data were subjected to ANOVA and significantly different means were separated using the least significant difference multiple comparison test at $P \leq 0.05$. Data were initially analyzed by date to determine fungicide and cultivar effects, and to check for homogeneity of variance. Data also were combined over years and analyzed by season to determine the significance of the main effects of fungicides, cultivars, and years and their interactions. The seasons were defined as follows: winter = January + February + March; spring = April + May + June; summer = July + August + September; and fall $=$ October + November + December.

Differences between cultivars and interactions involving cultivars were not significant, except for the three-way interaction in fall (Table 1). Fungicides and their interactions with years were significant for all seasons. Therefore, the effects of the fungicides for each year will be discussed for means averaged over the cultivars.

Spring. Quality ratings in spring were consistently high and ranged from 7.9 to 9.0 for the 3 years. During 1984, all of the fungicide treatments received higher quality ratings than the untreated control (Table 2). However, there were no significant differences due to fungicide for 1985 and 1986. The quality enhancement observed in 1984 was probably due to the effect of the fungicides on red thread. Red thread was the only spring disease problem. In May 1984 and 1987, red thread was severe and all fungicide treatments reduced disease (Table 3 ).
Summer. In 1984 and 1985, turf of all fungicide treatments had better quality than the control. In 1984, plots treated with triadimefon had the best quality, followed by iprodione, thiram, and benomyl. In 1985, triadimefon-treated plots exhibited the best quality, followed by iprodione and benomyl. In 1986, there were no significant quality differences attributable to fungicides. The generally improved summer quality of fungicide-treated PRG appeared to be due to the control of chronic but low levels of brown patch during summer. In July 1985, brown patch blighting was reduced significantly by all fungicides (Table 3). On most July and August rating dates, however, $R$. solani activity did not advance to a level where visual differences in blighting could be detected among fungicide treatments. The improvement in summer quality by fungicide treatments in the absence of conspicuous or severe disease activity corroborate observations from another Maryland study (Dernoeden et al., 1985).

Quality ratings in summer (range 5.4-8.0) were generally inferior to spring (range 7.98.7) and fall (range 7.1-9.0) ratings (Table 2 ). The major decline in quality during summer was due to production of seedheads, which began in May of each year. Culms remaining below mower height senesced, and all plots were brown from the dying and/or dead culms in June and July. High temperatures, occasional drought stress, and chronic, low-level brown patch also contributed to the poor summer quality of PRG.

Fall. In general, ryegrass quality during the fall was good, especially in 1985. In Fall 1984, fungicide-treated plots had signifi- cantly higher quality than untreated turf (Table 2). Triadimefon, iprodione, and benomyltreated plots had better quality than chlorothalonil-treated plots (Table 2). In 1985 and 1986, there were no quality differences among treatments.

Winter. Winter quality was generally poor due to low temperatures, which caused a tip dieback in both cultivars. Dead tips became grayish, giving PRG its overall winter dormant appearance. In 1985, iprodione-, thiram-, and triadimefon-treated plots were of better quality than untreated plots. According to 1985 field notes, iprodione-treated PRG resulted in best quality because of less tip dieback during winter. In 1986, only triadimefon resulted in higher quality than the control; no quality differences were observed in 1987.

Red thread significantly injured untreated plots in July 1984 and Dec. 1986 (Table 3). The enhancement of red thread by benomyl observed elsewhere (Burpee et al., 1978; Dernoeden et al., 1985; Smiley, 1981) did not occur in this study. Further, no fungicide treatment was associated with enhancement of any disease or reduction in quality of either cultivar during the study.

There are few reports describing the influence of multiple fungicide applications on turfgrass quality (Dernoeden et al., 1985; Kane and Smiley, 1983). There is evidence, however, that PRG quality and Kentucky bluegrass color can be enhanced by fungicides in the absence of severe disease pressure (Demoeden et al., 1985; Kane and Smiley, 1983). Improved quality accorded by fungicides may be attributed to control of severe as well as low-level endemic disease activity, color enhancement, improved rooting, increase in carbohydrates, and possibly by other plant growth regulating effects elicited by fungicides (Goatley and Schmidt, 1990; Kane and Smiley, 1983; Smiley et al., 1985).

In this study, quality was enhanced significantly by fungicides that controlled red thread and brown patch in Spring 1984 and Summer 1985, respectively. All fungicides improved summer quality in 1984 and 1985, and this was likely due to keeping low-level $R$. solani activity in abeyance. However, the mechanism of improved quality in other years and seasons was not determined conclusively. Hence, other than disease control, there were few nontarget benefits and no nontarget detriments visually associated with multiple 
fungicide applications to PRG. The influence of these fungicides on the ryegrass endophyte (Acremonium loliae Latch, Christensen \& Samuels), plant parasitic nematodes, and thatch and soil $\mathrm{pH}$ are discussed by Dernoeden et al. (1990).

\section{Literature Cited}

Burpee, L.L., P.L. Sanders, H. Cole, and J.M. Duich. 1978. Fungicide suppression of red thread in low nutrient status red fescue turf under home lawn management, 1977. Fungicide and Nematicide Tests 33:147.

Demoeden, P.H. 1989. Residual stripe smut con- trol in Kentucky bluegrass with reduced fungicide levels. HortScience 25:796-798.

Demoeden, P.H. and J.M. Krouse. 1990. Curative control of red thread in perennial ryegrass, 1989. Fungicide and Nematicide Tests 45:286.

Demoeden, P.H., J.J. Murray, and N.R. O’Neill. 1985. Nontarget effects of fungicides on turfgrass growth and enhancement of red thread. $p$. 579-593. In: F. Lemaire (ed.). Proc. 5th Intl. Turfgrass Res. Conf., Avignon, France. 1-5 July 1985. Institut National de la Recherche Agronomique, Paris, France.

Demoeden, P.H., L.R. Krusberg, and S. Sardanelli. 1990. Fungicide effects on Acremonium endophyte, plant parasitic nematodes, and thatch in Kentucky bluegrass and perennial ryegrass.
Plant Dis. 74:879-881.

Goatley, J.M. and R.E. Schmidt. 1990. Seedling Kentucky bluegrass growth responses to chelated iron and biostimulator materials. Agron. J. 77:597-602.

Kane, R.T. and R.W. Smiley. 1983. Plant growthregulating effects of systemic fungicides applied to Kentucky bluegrass. Agron. J. 75:469473.

Smiley, R.W. 1981. Non-target effects of pesticides on turfgrasses. Plant Dis. 65:17-23.

Smiley, R.W., M.C. Fowler, R.T. Kane, A.M. Petrovic, and R.A. White. 1985. Fungicide effects on thatch depth, thatch decomposition rate, and growth of Kentucky bluegrass. Agron. J. 77:597-602. 